\title{
Poemele homerice în veșminte românești. O analiză diacronică $(I)$
}

\author{
Petre Gheorghe Bârlea* \\ Facultatea de Litere, Universitatea „Ovidius”, Aleea Universității 1, 900472 Constanța, România
}

\begin{tabular}{ll}
\hline Despre articol & Rezumat \\
Istoric: & Lucrarea pe care o propunem vizează istoria traducerilor românești ale poemelor \\
Primit 14 martie 2015 & homerice, din perspectiva evoluției limbii române literare. Pornim de la premisa \\
Acceptat 22 martie 2015 & că orice asemenea traducere reprezintă o probă de virtuozitate nu numai pentru \\
Publicat 17 iulie 2015 & traducătorul în cauză, ci și pentru limba și cultura modernă respectivă, așa încît \\
& este interesant de studiat modul în care dezvoltarea exegezei homerice și a teori- \\
Cuvinte-cheie: & ilor traductologice se manifestă în paralel cu etapele evoluției limbilor moderne. \\
traducere & Grila de analiză va include, aşadar, principii, metode și instrumente de lucru \\
contact lingvistic & ale domeniilor amintite aici (istoria limbii, traductologie), dar și elemente îm- \\
diacronie & prumutate din gramatica constrastiv-tipologică, din filologie, în sensul restrîns \\
filologie & al conceptului, din teoria mentalităților, istoria culturală ș.a. Demersul nostru \\
limbă literară & evidențiază faptul că evoluția istorică a actului traducerii este marcată, în mod \\
& firesc, de personalitatea traducătorului (opțiuni teoretice, ideologice, pe lîngă \\
& competențe lingvistice, har poetic etc.), dar și de contextul cultural al epocii și \\
& al spațiului respectiv. Pentru cultura română, cel puțin, putem constata că, în \\
& ansamblu, versiunea cea mai recentă este și cea mai reușită.
\end{tabular}

\section{Introducere}

\subsection{Premise}

Orice traducere reprezintă o provocare și o validare a virtuților compensatoare ale limbii primitoare, dar traducerea marilor creații literare ale omenirii constituie examenul suprem, niciodată definitiv ${ }^{1}$, al virtuţilor unui idiom, o probă marcată în mod firesc de asumarea unor responsabilități față de cele două limbi, culturi și civilizații puse în contact. În ceea ce ne privește, ne menținem afirmația formulată în diverse alte contexte că un asemenea efort este perfect comparabil cu cel de creație originală în limba unui popor (Bârlea, 2014, p. 27).

În istoria modernă a filosofiei, traducerile din Homer sînt considerate o paradigmă a manifestării aşanumitelor „proceduri de control și de delimitare a discursului”, care domină întreaga existență a civilizațiilor lumii. Traducerile reprezintă o procedură internă, prin care un text fondator acționează cu de la sine putere asupra altor texte, ce se produc mereu în timp. Principiul de clasificare, ordonare și distribuție prin care se concretizează respectiva procedură este numit de Michel Foucault „comentariu”: un discurs care „se spune”, adică este stabil, etern, bine individualizat, generează discursuri care „se zic”, adică sînt schimbătoare, temporare, eterogene ${ }^{2}$. Reluarea la infinit a textelor homerice în diverse limbi este un exemplu tipic de comentariu, id est: de re-interpretare, înnoită în extrem de multe variante diacronice, diatopice și diastratice. În aceleași condiții funcționează și principiul „rarefierii textului” sau „principiul

\footnotetext{
*Adresă de corespondență: gbarlea@yahoo.fr.

${ }^{1}$ Se consideră, îndeobște, că orice capodoperă din literatura universală ar trebui re-tradusă în limbile moderne măcar la fiecare două generații de cititori, cf. Slușanschi, Postfață la DS-I, p. 505.

${ }^{2}$ „Comentariu” înseamnă, chiar și în terminologia lui M. Foucault, în primul rînd nesfîrșitele exegeze de texte, precum și, la extrema cealaltă, creațiile originale bazate pe teme, motive și tehnici literare homerice, în cazul de față, ca romanul Ulisse, al lui James Joyce.
} 
Petre Gheorghe Bârlea

autorului", complementar celui dintîi, ilustrat de asemenea paradigmatic de textele homerice, întrucît pun în discuție raportul unicitate/multitudine, cu privire la forma inițială a textului, și, implicit, la paternitatea discursurilor de tip primar/secundar (Foucault, 1998, p. 23-26).

\subsection{Materialul de lucru}

Analiza noastră se întemeiază pe edițiile „mari” ale textelor homerice fundamentale 3 —Iliada și Odiseea adică pe versiunile pe cît posibil integrale și definitivate (de către traducător sau de editori), dacă nu chiar definitive, în sensul discutat mai sus. Concret, am luat în considerare textele românești publicate între anii 1837 și 2012, pe care le-am împărțit, în altă parte (Bârlea, 2014, p. 27), în trei mari epoci, urmînd cele două criterii de analiză—a evoluției limbii române și a opțiunilor traductologice.

a) Secolul al XIX-lea, al începuturilor traducerii și al cristalizării limbii române literare moderne. Se încadrează aici Iliada, I-VI, tradusă în proză de C. Aristia și tipărită de I. Heliade Rădulescu, la București, în 1837 (CA-I), precum și Odiseea, în versiunea versificată a lui Ioan Caragiani, tipărită la Iași, în 1876, împreună cu Batrachomiomachia (IC-O).

b) Secolul al XX-lea, al diversității formelor traductologice (proză, vers original, vers modern, vers liber), al marilor elanuri în utilizarea limbii române (română literară standardizată, autohtonizare, latinizare, fond arhaic, popular, religios, neologic), al competiției și dezbaterilor pe marginea realizărilor românești și al revizuirilor rezultate din acestea. Epoca este ilustrată în primul rînd de îndelungata și larg recunoscuta activitate a lui George Murnu, care dă o versiune a Iliadei în hexametri originali în 1920, premiată de Academia Română (GM-I), dar care are o istorie a slujirii pe tărîmul textelor homerice de aproape un secol, căci între anii 1900 și 1995 au apărut zeci de fragmente publicate sub pana sa în reviste și volume colective, ediții parțiale și integrale, cu revizuiri, adnotări, studii datorate autorului sau unor mari personalităţi, inclusiv în două ediții... definitive, datorate lui D. M. Pippidi (GMD-I în 1967 şi GM-Od în 1971) şi două ediții „,̂̂n ultima formă”, datorate lui Liviu Franga (GMF 1 -I în 1985 și GMF 2 -I în 1995). „Poetul homerid” a ocupat cu atîta forță spațiul românesc al homerologiei, încît în tot secolul nu au mai fost editate alte versiuni de dimensiuni mari, deși criticile au fost aproape la fel de vii ca și laudele aduse marelui tălmăcitor. În schimb, au fost realizate patru traduceri diferite din Odiseea, semnate de G. Coșbuc (1902-1918, în vers modern, publicată integral abia în 1966, de I. Sfetea și Șt. Cazimir, GC-O); același G. Murnu (1924, în versuri albe, cu o revizie semnificativă în 1940); Cezar Papacostea (1929, în hexametru dactilic, numai primele 12 cînturi, reeditată în 2012, de Ioana Costa, $\mathrm{CP}-\mathrm{O})$; E. Lovinescu ( $\mathrm{EL}-\mathrm{Or} 1,1935$, traducere în proză, cu numeroase reluări: EL-Or2, EL-O, EL-Or3).

c) Sfîrșitul secolului al XX-lea și începutul secolului al XXI-lea reprezintă epoca post-și postpostmodernismului chiar și pentru procesul traducerilor. Noii tălmăcitori au fost beneficiarii marilor exegeze și ai edițiilor academice din lume a ultimilor cincizeci de ani. Este intervalul în care a apărut prima traducere românească în proză a Iliadei, datorată lui Radu Hâncu și Sanda Diamantescu (1981, HD-I, reluată numai cu semnătura lui R. Hâncu în 2011, RH-I), dar și traducerile integrale ${ }^{5}$ ale ambelor poeme în hexametru dactilic catelectic de Dan Slușanschi (Odysea, 1 1997/2012; Iliada, 2009/2012).

\footnotetext{
${ }^{3}$ Celelalte texte atribuite lui Homer, precum Marghites, Batrachomiomachia, Imnurile au fost traduse mai puțin tocmai pentru că nu se ridică la nivelul artistic al celor două mari poeme. Apocrifele homerice, paternitatea celor două poeme și personalitatea lui Homer însuși constituie ceea ce în cercetarea filologică de specialitate se numește 'problema homerică', cf. Marinescu-Himu \& Piatkowski (1972, p. 54-58).

${ }^{4}$ Pentru grafierea titlului celei de-a doua epopei homerice, am optat pentru forma încetățenită în filologia românească—cu $s$ și $e e$.

${ }^{5}$ Cîteva versuri sau porţiuni de versuri, care nu au mai putut fi recuperate din arhiva traducătorului, au fost completate de Francisca Băltăceanu, în edițiile postume realizate de colectivul editorial de la „Humanitas” (DS-Or).

${ }^{6} \hat{I}$ acest caz, preluăm grafia traducătorului, care ținea mult la acest aspect. De altfel, pentru titlul ales de fiecare traducător, am păstrat formele respective în Bibliografie.
} 
$\mathrm{Nu}$ am luat în considerare versiunile așa-zis „experimentale”, fragmentare, pe cît de numeroase, în diacronia homerologiei românești, pe atît de captivante, căci datorate, adesea, unor personalități care și-au demonstrat din plin și erudiția și talentul ${ }^{7}$. Anterioare sau posterioare edițiilor de referință pe care le-am selectat aici, ele vor fi menționate numai în legătură cu anumite particularități lingvistice, atunci cînd ni se va părea că oferă variante și soluții interesante pentru problematica noastră. Motivele ignorării istoriei lor sînt lesne de înțeles: spațiul expunerii de faţă s-ar fi mărit nepermis de mult. Au rămas în atenția noastră versiunile de referință pentru cultura românească: patru traduceri din Iliada și șase traduceri din Odiseea, realizate în 172 de ani de evoluție a limbii române literare.

\subsection{Metoda de lucru}

Grila noastră de analiză este alcătuită preponderent din itemi lexico-semantici, cu referire la lexicul general, dar cu privire specială asupra onomasticii (mitonimie, antroponimie, toponimie etc.) și asupra unor arii terminologice precum fitonimele și zoonimele, termeni anatomici, numele care desemnează diverse tipuri de ierarhii umane și divine etc. Urmărim apoi cum este structurat gramatical acest întreg material, prin anumite selecții morfologice și sintactice, din perspectivă contrastiv-tipologică. Fonetismul acestor structuri lexico-gramaticale și stilistice va fi analizat numai acolo unde opțiunea este vizibil orientată voluntar. Formele expresive vor fi cercetate la nivel microtextual și macrotextual, de la selectarea susceptibilă de intenție stilistică a unui termen, a unei expresii, a unui vers, pînă la structurile compoziționale generaletablouri, episoade, cînturi, mari secvențe tematice. Maniera de transpunere discursivă—proză, versuri (originale-antice, medievale, moderne)-, care justifică în măsură covîrșitoare această întreagă serie de selecții lexico-gramaticale, va fi supusă analizelor și într-o secțiune separată, după celelalte niveluri ale scriiturii, pentru că aceste formule constituie un aspect de sine stătător al evoluției unei limbi, în varianta sa literară. Oricum, se înțelege că fiecare compartiment lingvistic le determină pe celelalte, nucleul constituindu-l opțiunea lexico-semnatică, și că ordinea abordărilor noastre nu va rămîne fixă, ci se va adapta în funcție de caracteristicile cele mai pregnante ale fiecărei versiuni studiate. În sinteză, ceea ce își propune să redea traducătorul este, în primul rînd, „atmosfera”, spiritul lumii homerice—cu determinările sale concrete, spațio-temporale, cu elementele de realia, cu mentalitățile și modul de comunicare tipice, totul re-creat în noua matrice etno-lingvistică prin intermediul cuvintelor.

Practic, această grilă analitică sui generis (care nu are nici pretenția rigurozității absolute, nici pe cea a exhaustivității) se va aplica după criteriul cronologic —etape ale traducerii, ordinea temporală a apariției versiunilor românești-, coroborat cu evoluția limbii române și a tehnicilor traductologice, dublat de criteriul structural, impus de aspectele fonologice, lexico-semantice, gramaticale și stilistice care se învederează semnificativ în fiecare text analizat.

Ca bază de analiză, am tratat în paralel patru fragmente considerate de noi reprezentative ${ }^{8}$ pentru modurile de exprimare din cele două poeme epice:

a) Un scurt episod din Iliada, XII, 42-52 (căderea lui Euforbos) - pentru caracterul dinamic al narației, cu elemente realist-descriptive, naturaliste, chiar.

b) Descrierea de natură din Odiseea, V, 61-75 (intrarea în peștera nimfei Calypso)-pentru lirismul tabloului poetic.

c) Dialogul Atena-Nestor, din Odiseea, III, 329-336-pentru tipul de discursivitate uzuală, eliberată de canoanele ,înfruntărilor” în vorbe și în fapte, din scenele de război.

d) Înfățișarea finalului tragic al luptei dintre tracul Peiróos și grecul Dióres, din Iliada, IV, 517-526, cu moartea celui din urmă, descrisă în culori crude, naturaliste, tipice pentru primul poem homeric. În

\footnotetext{
${ }^{7}$ Contribuții interesante la istoria traducerilor românești din Homer au avut Iosif Kontz, Moise Nicoară, Alecu Beldiman, Gh. M. Herescu, George Seulescu, Al. I. Odobescu, M. Eminescu, Ștefan Bezdechi, N. Iorga, Constantin Balmuș ș.a., cf. Lascu (1974, p. 198-217), Georgescu (2005, p. 31-51).

${ }^{8}$ Precizăm că „reprezentativitatea” pe care o vizăm aici este una personală, strict tehnică, adaptată la necesitățile de analiză propusă de noi. Nu este vorba despre pasaje și episoade celebre în receptarea textelor homerice, precum invocațiile inițiale, descrierea scutului lui Ahile și altele de acest fel, deși acestea ne-ar fi oferit, cu certitudine, sugestii hermeneutice și un material analitic mult mai bogat.
} 
paginile de faţă, reținem numai comentariul episodului enumerat aici sub punctul a).

Evident, cadrul referințelor se va lărgi mult, cu exemple din diverse alte pasaje ale textelor homerice, în conformitate cu frecvența sau specificitatea unor opțiuni textuale prin care fiecare traducător român a încercat să redea ideea și cuvîntul din creația aedului elin.

Selecția noastră a avut drept criterii de bază, cum spuneam, reprezentativitatea pentru stilul, tipologia modalităților de redare narativ-literară a substanței poemelor (dinamice, descriptive, dialogice), dar și existența unui număr cît mai mare de versiuni românești ale pasajelor respective.

Acesta este motivul pentru care am ocolit fragmente celebre, frecvent exemplificate în istoria universală a exegezelor homerice. Obiectul nostru de studiu fiind limba română în care s-au transpus poemele homerice, am căutat părțile din epopei care să reflecte particularități ale evoluției românei literare, mai degrabă decît frumusețea unanim recunoscută a unui tablou, a unui discurs etc. din textul original. Faptul că prima mare traducere din Iliada (CA-I) nu cuprinde decît primele șase cînturi, ne-a obligat să selectăm un fragment din această parte a poemului, ca să avem în față evoluția marcată de toate cele patru traduceri „mari” în română. Fragmentul Il., XVII, 42-52 constituie o excepție de la acest principiu, explicabilă mai puțin prin nevoia de clarificare a unor opțiuni lexicale cu privire la un anumit tip de terminologie specială—terminologia anatomică, deja discutată la fragmentul a), cît prin interesul pe care îl poate suscita structura compozițională ireproșabilă a microunităţilor poemului homeric: dialog pregătitor - confruntare armată - final tragic pentru unul dintre luptători - comentariu filosofic (1 și 2), prin comparații și analogii privind succesiunea viață/moarte.

Perspectiva a rămas, în principiu, aceeași: am urmărit capacitatea limbii române, în diversele subetape din cele aproape două secole de echivalare, de a reda textul-sursă în mod fidel și creator, totodată.

\subsection{Precizarea termenilor}

În demontarea unităților logice care alcătuiesc eșafodajul poemelor homerice, utilizăm termeni preluați de științele cuvîntului, mulți dintre aceștia reflectînd, cum se știe, sinestezia-ceea ce la nivel teoretic înseamnă interferența parțială—cu terminologia artelor vizuale. Un cînt (rapsodie, carte) din cele douăzeci și patru convenționale ale fiecărui poem este alcătuit din episoade, acțiuni secundare, relativ independente, delimitate, de obicei, prin trecerea de la un mod de expunere la altul, dar incluzînd mai multe asemenea moduri. Prin scenă înțelegem subdiviziunea dominată de unul sau mai multe personaje sau de o acțiune bine individualizată. De exemplu, episodul luptei dintre Menelau și Euforbos se întinde pe 69 din cele 761 de versuri ale Cîntului al XVII-lea al Iliadei, fiind alcătuit din scene de luptă, scene ale morții, dar și din dialoguri, scurte descrieri de natură și litanii-comentariu, iar dacă luăm în calcul și intervențiile zeilor, apărarea trupurilor/armelor celor învinși, episodul cumulează 139 de versuri. Toate aceste subdiviziuni sînt numite în paginile de față tablouri-dinamice sau statice, dacă înfățișează momente diferite și locuri diferite ale unor acțiuni sau peisaje. Ele sînt impregnate cu dialoguri/discursuri, aparté-uri, comentarii (scurte) ale aedului. Gruparea unora dintre acestea, de tipul înfruntare verbală, înfruntare armată, eventual, și 'scurt comentariu' alcătuiesc, în terminologia noastră, un pasaj sau un fragment din episod. Ultimul termen poate fi folosit și atunci cînd delimităm numai o parte dintr-un tablou; în asemenea situații, facem precizarea de rigoare la locul cuvenit. Prin unitate logică înțelegem conceptul impus de hermeneutica homerică-o idee, o acțiune etc. sau o grupare coerentă de informații concentrate, de obicei, într-o succesiune scurtă de versuri sau chiar într-un singur vers, după principiul 'o idee - un vers', cf. infra, \$2. Termenii enunt, frază, vers, emistih ș.a. sînt folosiți în sensul uzual din tratatele de sintaxă, prozodie etc.

\section{Arta cuvintului în epopeile homerice}

2.0. Ca să înțelegem dificultățile pe care le-au avut de înfruntat tălmăcitorii români în abordarea textelor homerice, trebuie să ne reamintim în ce constă homerismul lingvistic și stilistico-prozodic al acestora. Comentatorii traducerilor românești au avut în vedere, cu excepția tratatelor academice, respectiv a cursurilor universitare, numai unele dintre aceste particularități. Fiecare exeget a vizat ceea ce a crezut mai 
interesant și ceea ce părea relevant la nivelul informației științifice din epoca respectivă. Ceea ce se știa, însă, foarte bine, încă din Antichitate, de altfel, este faptul că cele trei mari categorii de aspecte ale poeticii formale-limba, stilul, prozodia-trebuie analizate împreună, căci s-au condiţionat reciproc, încă din primele versiuni ale epopeilor în discuție. Ele alcătuiesc o limbă poetică ideală, neatestată concret la vreo comunitate de vorbitori reali, numită ca atare „limbă homerică” sau "greacă homerică”. Or, de acest lucru au fost obligați să țină seama și traducătorii în limbile moderne.

2.1. Desigur, diversele componente ale acestui idiom special au fost preluate din vorbirea populațiilor lumii homerice, în zorii epocii istorice. În principiu, fondul lexical este ionic arhaic, impregnat cu elemente eolice și cu diverse alte variante dialectale ${ }^{9}$. Dacă reținem faptul că încă din Antichitate editorii au intervenit în texte, unii pentru a înlocui arhaismele cu forme mai evoluate (introducerea augmentului sau eliminarea dualului, de pildă ${ }^{10}$, iar alții, dimpotrivă, pentru a re-arhaiza limba, înțelegem de ce traducătorii din epoca modernă recurg la soluții contradictorii, pe parcursul aceluiași episod epic transpus în limba națională respectivă.

2.2. Revenind la epocile prime ale genezei epopeilor, acelea din „secolele obscure”, o a doua realitate de care trebuia să se țină seama este necesitatea turnării acestui eterogen material lexical în tiparul metric deja consacrat încă din perioada miceniană, respectiv în hexametrul dactilic catalectic. Acesta impune selectarea unui anumit cuvînt dintr-o serie sinonimică sau dintr-un cîmp semantic, dar și o anumită formă dialectală, funcțională etc. a respectivului termen—cu aspect dactilic, de preferință (două silabe lungi și una scurtă) sau, în orice caz, cu un număr precis de silabe, cu o succesiune stabilă a vocalelor și consoanelor, cu savante combinații ale sunetelor (închise, deschise, sonore, lichide, vibrante etc.).

2.3. De aici decurge un al treilea aspect al limbii homerice: alternanțele cantitative ale segmentelor versului dactilic cu șase picioare metrice determină nu numai selecții fono-lexicale, ci și fono-morfologice și topicosintactice. Forma lungă sau scurtă a unui verb, contragerea unui substantiv sau pronume, preferința pentru sintagme de o anumită structură, folosirea parataxei în raporturile de subordonare și coordonare sau, invers, plasarea unui conector redundant, acolo unde ritmul îl cere, contribuie, toate, la strunjirea versului epic de tip homeric.

2.4. Și, încă, un al patrulea mare grup de tehnici care generează versurile homerice vizează pauzele cu efect „răsunător”, repetiţiile concretizate în cunoscutele epitete-clișeu și sistemul formular al frazelor-tip (incipit-uri, finaluri de unități logico-sintactice, formule fatice, reluări). Traducătorii moderni invocă mai ales acest aspect al versului eroic grecesc, cunoscut în homerologie sub numele de „sistem epic formular”. În prima subcategorie intră: a) sintagme atributive de tipul „cel iute de picior” (Ahile), redat uneori ca „, soimanul Ahile”, „Ahile cu fuga în picioare”; „cutremurul lumii” (Poseidon); b) invariante sintagmatice de tipul formulelor de adresare, de îndemn („Ares, tu, crîncene, biciul orașelor, pacostea lumii”), al descrierilor de situații tipice („Cade pe loc, răbufnind și zuruie-arama pe dînsul”), al concatenărilor sintactice ample, în spirală sau în cercuri concentrice („Astfel grăi, și zîmbit-a zeița cu ochi verzi, Athena,/Și-l mîngîie cu-a ei mînă - la trup semănînd cu-o femeie/'Naltă, frumoasă și mult știutoare de mari meșteșuguri” (DS-Or, XIII, 287-289). Cf. și „După ce glia ascunse și neamul acesta de oameni”, Hesiod, Munci şi

\footnotetext{
${ }^{9}$ Avem în vedere versiunile fixate în scris, bazate pe copiile manuscrise antice și medievale, ale căror filiații pot fi reconstituite cronologic pînă la vulgatele postalexandrine, cf. Marinescu-Himu \& Piatkowski (1972, p. 103).

${ }^{10}$ Dintre filologii din Alexandria și din Pergamon care au contribuit decisiv la stabilirea unor versiuni „editabile”, Aristarh din Samothrace (216-144 a. C.) „a plivit” cu cel mai mare sîrg textele vechi, respectiv, pe cele transmise din sec. al VII-lea - al VI-lea a. C. Preluînd directoratul Bibliotecii din Alexandria de la Aristofan din Bizanț, a continuat și munca acestuia de diortositor al operei homerice. În ediția sa-devenită text de referință pentru multe secole de atunci încoace-a ales în mod sistematic, prin aplicarea principiului anaforic, cuvîntul cu semantism clar în locul celui polisemantic sau obscur prin vechime, prin încărcătură metaforică etc., a privilegiat cuvîntul atestat de lexicografi, dar și de limba vie, și a folosit accentele, semnele grafice pentru cantitate, semne prozodice care explicau mai bine selecția lexico-semantică.
} 
zile, v. 135 și 151, trad. Șt. Bezdechi); c) redarea unor acțiuni sau prezentarea unor obiecte, veșminte, ritualuri etc. prin grupări de versuri, care trebuie să constituie o unitate, chiar dacă în ansamblul cîntului ele reprezintă paranteze, intervenții suplimentare-este vorba despre acele retardationes, specifice mai ales Iliadei.

2.5. Al cincilea nivel se situează într-un strat mai subtil și, în consecință, mult mai dificil al corespondenței dintre „planul ideatic și cel al expresiei” (Marinescu-Himu \& Piatkowski, 1972, p. 105). Indiferent dacă succesiunea părților constitutive se baza pe o simetrie sau pe o opoziție, pe o comparație amplă sau pe o dezvoltare metaforică, alegorică etc., aedul căuta ca o idee să încapă confortabil și pregnant într-un vers, într-un diptic sau, in orice caz, într-o grupare de hexametri bine determinată. Desigur, în fiecare poem există suficiente exemple de discordanțe microcompoziționale logico-expresive, chiar și după eliminările practicate în faza orală a circulației rapsodiilor homerice și, mai ales, în faza diortosirilor academice din epoca fixării în scris și a edițiilor savante-alexandrine și postalexandrine. Dar aspirația spre desăvîrşire este evidentă: fiecare hexametru cată să reprezinte o idee profundă, un sentiment înalt, cu o logică internă de nezdruncinat, totul turnat într-o formă strălucitoare și perfect acordată cu natura conținutului. Apoi, fiecare hexametru astfel strunjit trebuie să se integreze fără smintire în ansamblul episodului, rapsodiei şi, prin acesta, poemului, în întregul lor. Rezultatul final este menit să fie o capodoperă de arhitectură textuală, care adăpostește un tezaur de gîndire și de sensibilitate antică, a cărui valoare a crescut continuu în timp.

2.6. Cu aceasta, însă, am ajuns la al șaselea nivel al artei homerice-acela al macrostructurilor. Cele două poeme sînt înrudite tematic, dar reprezintă perspective diferite asupra legendarului război troian, ceea ce înseamnă, în terminologia actuală, două subiecte diferite. Acestea, la rîndul lor, reprezintă epoci diferite (reflectate ca atare, în geneza propriu-zisă a poemelor), mentalităţi diferite, structuri compoziţionale diferite, tehnici poetice diferite, în ultimă instanță. Iliada este un diptic compozițional, consacrat celor două teme fundamentale, „mînia” lui Ahile și „,voința” lui Zeus. Acțiunea, liniară, asincronă, este dominată de personaje eroice și de zei (aproape în egală măsură), caracteristicile principale fiind dinamismul şi retorismul. Odiseea este un triptic circular consacrat nòstos-ului („întoarcerii”) lui Odiseu și compus din a) Telemahia - călătoria lui Telemah în căutarea informațiilor despre tatăl său; b) rătăcirile lui Odiseu (nòstosul propriu-zis); c) regăsirea Ithacăi, cu toate surprizele așteptate, acțiunea desfășurîndu-se pe mai multe planuri paralele, fie simultan, fie după o logică particulară a succesiunii cronologice și cu un punct final convergent, faptic și dialogic, în același timp-mnesterofonia „uciderea pețitorilor”. Procedeele de compoziție sînt mai variate-dramatic, narativ, descriptiv—, iar comparațiile, metaforele și alegoriile sînt mai numeroase și mai subtile în a doua epopee ${ }^{11}$. Materialul lexico-semantic, structurile gramaticale și stilistice se adaptează necontenit acestor procedee, tehnici și strategii discursive, modificîndu-se în mod corespunzător manierei de a se aşeza în aceleași tipare ale hexametrului dactilic catalectic.

2.7. Aceste constrîngeri erau valabile pentru textul poemelor antice, în care exista însă libertatea aezilor de a găsi pe loc cuvîntul și forma care li se păreau mai potrivite pentru exprimarea ideii. În cazul traducătorilor, apare un nivel în plus al constrîngerilor, acela impus de fidelitatea faţă de textul-bază. În principiu,

\footnotetext{
${ }^{11}$ Dintre caracterizările memorabile ale celor două epopei, merită reținută cea aparținînd autorului anonim al Tratatului despre sublim, care consideră că Iliada este creația de maturitate a lui Homer, iar Odiseea - cea de la bătrînețe. Dincolo de faptul că exegeții consideră că distanța în timp între cele două epopei este mai mare-de circa un secol, atît ca civilizație descrisă, cît și ca epocă a compunerii formelor integrale, ceea ce anulează concepția paternității unice一, observația Anonimului este pe cît de greșită, pe atît de plastică: „În Odiseea, Homer este ca soarele la asfințit, care-și păstrează măreția, dar e fără putere”. Iliada, în schimb, este un „poem dramatic și furtunos”, are înălțime de stil, o multitudine de pasiuni, vioiciune și vigoare în discursuri, bogăție de imagini luate din lumea reală, îndemnuri la mari fapte. În aceste condiții, Odiseea se reduce la un basm în care sînt narate rătăciri de necrezut, cf. Tratatul despre sublim, ed. C. Balmuş, 1935, p. 38-39. Mai profundă, însă, rămîne caracterizarea făcută de Aristotel, bazată, de asemenea, pe o opoziție: Iliada este un „poem simplu și patetic”, iar Odiseea este un „poem complex” (cf. Aristotel, 1965, 1459b, 16).
} 
traducerea în limba străină înseamnă echivalarea prin cuvintele cu exact aceeași semnificație, din același registru funcțional-stilistic și cu aceleași forme gramaticale, în măsura în care acestea există în limba-țintă. Problema diferențelor contrastiv-tipologice, care constituie deja o sursă de mari dificultăți, în acest sens, este dublată, cum știm, de marea problemă a versificației. Faţă de versul grecesc, bazat pe cantitatea silabelor şi pe o melodicitate obținută prin succesiunea lungimii și a accentului fonemelor, combinate cu efectele timbrului, ale ritmului și pauzelor etc., versul modern uzeză numai de două dintre acestea și într-o manieră mult schimbată—rima posibilă este numai una dintre schimbări.

2.8. Or, toate acestea înseamnă o luptă nesfîrșită pe cele două fronturi-al limbii textului-bază, care trebuie înțeles foarte bine, în subtilitățile sale lingvistice și contextuale, precum și al limbii textului-țintă, care trebuie să redea, cît mai fidel și la fel de pregnant artistic, dacă este posibil, respectivele subtilităţi. Opțiunile prime ale traducătorilor - versiuni în proză, versiuni în metru antic, versiuni în metru modern-înseamnă, dintru început, sacrificarea unora dintre aspectele enumerate mai sus. Decizia nu este dacă o fac sau nu, ci $c \hat{\imath} t$, anume și $c e$, anume se resemnează să sacrifice fiecare traducător. Iar lupta pentru re-crearea poemelor în haina nouă a limbilor proprii începe abia după aceste dureroase decizii de ignorare voluntară a unora dintre particularitățile sesizabile ale originalului. Cît despre chinuitoarele loca obscura, problema nici nu mai este asumată de traducători, acum, cînd exegeza a devenit o profesie de sine stătătoare...

\section{Mărturiile textelor homerice}

Selectarea unor fragmente din textele homerice în vederea unei analize lingvistice confirmă două afirmații aparent contradictorii făcute mai sus: a) bogăția și plasticitatea idiomului homeric nu poate fi ilustrată la adevarata sa valoare prin analize fragmentare; b) orice fragment reflectă întregul, căci decantarea compozițională și lingvistică a poemelor, produsă lent, de-a lungul a sute de ani, a conferit coerență de sistem poemelor, astfel încît fiecare detaliu are corespondențe cu celelalte detalii, la scară din ce în ce mai cuprinzătoare (tablouri, episoade, cînturi), precum și cu întregul, în același timp, iar acestea din urmă depind și le determină pe cele dintîi, tot concomitent, ca în cazul unui organism viu.

Operațiile de de-structurare care urmează au valoare preponderent metodologică, impusă de uzanțele analizelor de limbă pe un text dat. Observațiile cu caracter general sînt formulate, aşa cum am arătat în rîndurile privind recursul la metodă, prin raportare la textul integral al poemelor homerice.

\section{1. „Nemilostivul pietroi”. Moartea lui Diores (Hom., Il., IV, 517-526)}

Tipică pentru scenele de un tragic naturalism din Iliada, fragmentul Il, IV, 517-526 urmează unei succesiuni de tablouri similare, care alcătuiesc episodul epic al luptelor din finalul Cărții a IV-a, după reațițarea războiului, cauzată de încălcarea jurămintelor, și după orînduirea oștilor de către Agamemnon. Antifos îl ucide pe Leucos, tovarășul lui Odiseu (490-493); mînios, acesta din urmă îl ucide pe Democóon, fiul din flori al lui Priam (494-504). Nu lipsesc cele două scurte discursuri preliminare, cu deosebirea că acum numai zeii sînt cei care vorbesc. Întîi sînt reproduse cuvintele lui Apollo, care îi îmbărbătează pe troieni (507-514), apoi aedul notează scurt că, de cealaltă parte, Athena îi îndeamnă la luptă pe ahei (515-516).

Asemenea fragmente sînt reprezentative pentru caracterul eminamente războinic al lumii zugrăvite în Iliada. Sînt exprimate aici cu înfricoșătoare precizie modul în care sulița, lancea, săgeata, sabia, buzduganul, pietroiul ș.a. străpung, sparg, rup diverse părți ale corpului uman, cu detalierea sfărîmării și împrăştierii oaselor, tendoanelor, organelor, pielii, sîngelui. Scurte notaţii redau ultimele gesturi ale războinicului muribund, surpriza celui care sperase pînă în ultima clipă că pe el soarta îl va cruța, durerea, spaima, nepăsarea, reacțiile deseori neașteptate, grotești, uneori, ale învinsului și ale învingătorului. În scurte cuvinte este exprimată disperarea victimei și orgoliul ucigașului. Continuarea vine ceva mai îmblînzită, ca o contrapondere față de aceste imagini crude: tovarăşii de arme încearcă să-l tîrască pe cel căzut în afara scenei de luptă, un camarad înfuriat preia imediat contraatacul, atacatorul victorios cade el însuşi victimă altei lovituri, mai mult sau mai puțin întîmplătoare. Interludiile lirice minimale sînt nelipsite, 
Petre Gheorghe Bârlea

în repetitivitatea lor, formulele fixe anunță vălul de întuneric care acoperă ochii învinsului, comparațiile cu elemente din natură (regn vegetal, animal) atenuează prin generalizare şocul trecerii celui căzut spre Universul primitor, dar nepăsător, discursul justifică într-un fel deznodămîntul și anunță o nouă încleștare:

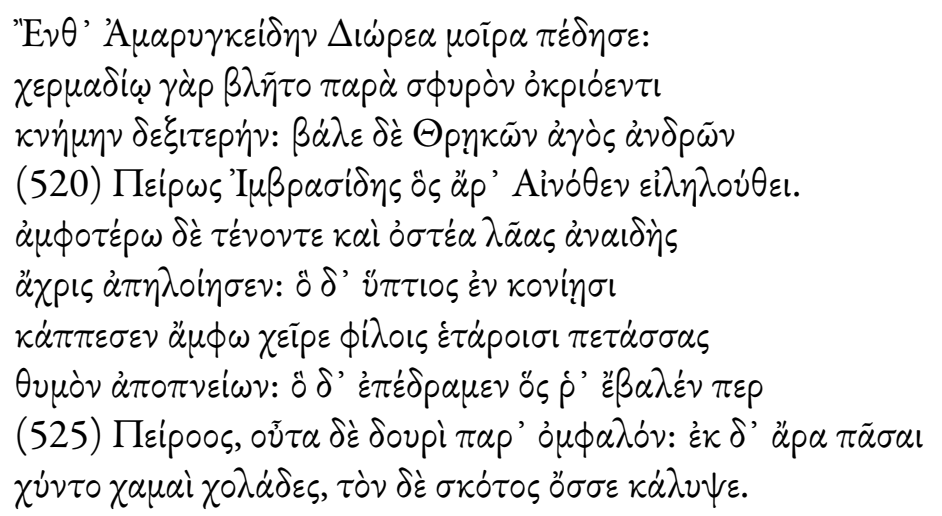

(Hom., Il., IV, 517-526)

Firul epic revine brusc la șirul de descrieri crude ale morții eroilor, cu o notație introductivă scurtă, ce include în ea atît informația seacă, neutră, cît și comentariul filosofic despre destinul neiertător:

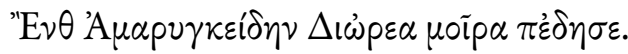

Traducerile românești sînt impregnate, fără excepție, de sobrietatea versului original:

Aici a legat soarta p'Amarințid Dior. (CA-I, IV, 517)

...Pe Dior, Fiul lui Amarinceu, ursita-l robi pe vecie. (GM-I, IV, 516-517)

Soarta cade näpraznic asupra lui Diòres, ful lui Amarinceu. (HD-I, IV, 517)

Darpe Diores ${ }^{12}$ al lui Amarynkes grea soartă-l răpuse. (DS-I, IV, 517)

Interpretarea nu ridică mari probleme, în pofida sintetismului enunțării. Termenul inițial, हैं $\vartheta(\alpha)$ (adverb demonstrativ cu valoare temporală sau adverb relativ cu valoare spațială) este luat drept adverb de timp, în versiunea CA-I, și conjuncție coordonatoare adversativă, în DS-I. Gramatical, este mai justificată traducerea „în acel(aşi) loc”, „tot acolo”, iar logic, opoziția s-ar putea face cel mult faţă de moartea recentă a lui Democóon, scenă rămasă prea mult în urmă și întreruptă de interludiile oratorice. Așa încît respectarea cuminte a sensului propriu al termenului cu rol de incipit din textul românesc vechi (1837) pare soluția cea mai corectă.

Deosebirile mai mari apar în secvența acțiunii destinului. Ca de obicei, G. Murnu inovează cel mai curajos, adăugînd la final circumstanțialul de timp, pe care CA-I îl crezuse mai nimerit la începutul secvenței, interpretînd sensul verbului și ducînd întregul enunț pe mai mult decît un vers, cum cerea specificul textului homeric (o idee - un vers; o unitate legică dezvoltată pe un tablou - un grup unitar de versuri). Concret, sintagma grecească $\mu$ iij $\alpha \pi \dot{\varepsilon} \delta \eta \sigma \varepsilon$ s-ar putea traduce prin „soarta îl împiedică (să-și continue)”. Verbele „a robi”, ,a cădea (năpraznic), ,a răpune” sînt, evident, mai puțin aproape decît „a lega” din original ( $\pi \delta \delta \delta \dot{a} \omega$ „leg, împiedic, înlănțui”), dar completările focusului verbal sugerează o dată în plus modul de acțiune al Destinului. Acesta însuși este numit, în general, prin termenul încetățenit în româna literară standard, soartă, cu așteptata căutare a sinonimului neaoș la GM-I - ursită și cu epitetul grea, la DS-I, care deplasează aici în plan nominal complinirile grupului verbal din celelalte versuri.

Scena propriu-zisă a uciderii este întreruptă doar de nelipsita identificare a făptașului-erou, obișnuită în asemenea secvențe. În rest, detaliile mecanice și anatomice sînt descrise în toată cruzimea lor-rece, detaşat, tehnic-, acestea vizînd inclusiv gestul final al brațelor întinse rugător, care reia notarea scurtă a unor reținute semne de compasiune și reflecție umană, strecurate discret și în versul ințial. Redăm scena integral în versiunea DS-I, poate cea mai exactă, mai nuanțată lingvistic și stilistic, în acest caz:

\footnotetext{
${ }^{12}$ În ediția DS-I, p. 84, numele este cules greșit: Diones.
} 
Cu un pietroi ascuțit, spre călcîi, pe sub pulpa dreaptă

Îl nimeri căpetenia Tracilor, Peiroos, fiul

Drag al lui Imbrasos, care sosise aici de la Ainos.

Vinele lui, amîndouă, și osul i-l sparse deodată

Nemilostivul pietroi, iar in pulbere el, jos, pe spate,

Se prăbuşi, intinzînd către soții săi dragi stinse brațe.

Cum sta și sufletu-și da. Către el veni-n fugă, și lancea

Drept în buric i-o infipse, de-i curseră mațele-afară,

Peiroos, färă cruțare - pe ochi de-i lăsă bezna morții.

(Ds-I, IV, 518-526)

În astfel de situaţii, limba-țintă şi mînuitorul ei trebuie să urmeze îndeaproape această cumplită alternare între fixitate idiomatică și creativitate lexico-gramaticală, într-o stare de tensiune comparabilă cu a eroilor din scenele redate pentru cititorii unei lumi noi.

Evoluția limbii române literare, dar și evoluția acurateței echivalărilor lexicale, bazate pe o tot mai știinţifică exegeză a textului original, se pot urmări în terminologia anatomică umană, în primul rînd. De la „perve” (CA-I), la „vine” (GM-I și DS-I) și apoi la „tendoane” (HD-I), drumul lexicului anatomic românesc înaintează hotărît, nu fără ocolișuri (pentru gr. sg. $\tau \dot{\varepsilon} v \omega \nu$, aici, la dual). Pentru grecescul $\tau \dot{0}$

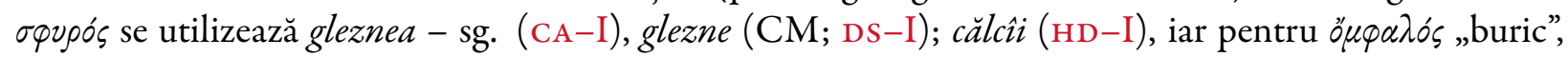

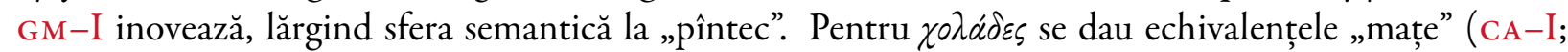
DS-I) și „măruntaie” (GM-I; HD-I). În asemenea cazuri, este vorba despre variaţii de acoperire semantică în terminologia de specialitate, mai mult decît despre interpretarea dată de traducător, căci opțiunile configurează vocabularul tehnic, totuși. La un nivel mai ridicat de subiectivitate a selecției echivalențelor se află construcțiile gramaticale cu caracter fix, standardizate, precum este grupul N+G al apartenenței, din onomastica personajelor, în română și în alte limbi moderne. Homer folosește construcțiile patroni-

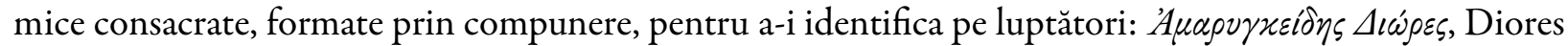

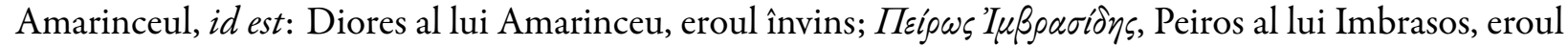
învingător, ca în alte sute de situații similare din poem. Traducătorii moderni ${ }^{13}$ simt nevoia să marcheze prin termenul concret ideea de filiație, căutînd uneori sinonimul cît mai expresiv sau însoțindu-l pe cel denotativ cu un epitet hipocoristic. Acest lucru se întîmplă chiar și în versiunile românești în proză, unde termenii supletivi nu au nici măcar justificarea necesităților metrice și prozodice. Excepție fac CA-I și DS-I, dar numai în cazul primului nume. Costache Aristia simplifică grupul nominal N-G la N-N, probabil pentru că formula „al lui...” i se păruse prea populară, de evitat într-o epocă în care el tocmai lupta pentru ieșirea de sub tirania acestor sintagme în formarea unei limbi literare supradialectale.

Amarințid Dior (CA-I, IV, 517)
Diores, fu al lui Amarinceu (GM-I, IV, 506-507)
Diores, Fiul lui Amarinceu (HD-I, IV, 517/70)
Diores al lui Amarynkes (DS-I, IV, 517).
Prințul... numit Imbracid Piros (CA-I, IV, 519-520)
Răsadul lui Imbrasos, Pirus (GM-I, IV, 509)
Pèiroos, vlăstar al lui İmbrosos (HD-I, IV, 518/70)
Peiroos, ful /Drag al lui Imbrasos (DS-I, IV, 519-520)

Ca de obicei, GM-I merge foarte departe cu „invenția” lexicală, căutind termenul cel mai puternic marcat, chiar dacă asta însemnă valorificarea unor cuvinte arhaice, dialectale și, în cazul lui „răsad”, numai metaforic

\footnotetext{
${ }^{13}$ Folosim termenul generic „modern”, pentru a sublinia că nu numai traducătorii români procedează astfel, ci și englezii, francezii, sîrbii ș.a., deși toate limbile moderne au în sistemul variantelor arhaice și populare formula onomastică bazată pe genitivul filiației paterne: „X al lui Y”.
} 
potrivite contextului. CA-I și DS-I cultivă și ei extremele, fiind cind (foarte) fideli originalului - Dior(es), cînd luîndu-și libertăți explicabile, cum arătam mai sus - Piros/Peiroos. Versiunea HD-I ar reprezenta un oarecare echilibru între aceste opțiuni.

Cum era de aşteptat, căutările traducătorilor se soldează cu încă mai mari variații în sintagmele cu atribut-epitet, din formulele relativ fixe care constituie foarte parcimonioasele comentarii lirice inserate sintetic în aceste tablouri ale morții crîncene, cu care se sfîrșesc scenele de luptă din Iliada. Există cel puțin trei asemenea formule în pasajul analizat aici, în afară de cea inclusă în versul deja citat mai sus, al introducerii în scenă: brațele victimei întinse moale spre camarazi; suflarea din urmă și, oarecum redundant, bezna care-i acoperea ochii. Prima dintre acestea face parte dintr-o serie mai variată de gesturi sfîsietoare, profund umane, în tragismul lor, puternic contrastante cu descrierea brutală a mediului războinic. Celelalte două sînt formule fixe, extrem de frecvente în întregul poem. Numai în Cîntul al IV-lea al Iliadei, unul predominant narativ, dinamic și obiectiv, formula lirică a stingerii complete din viaţă se repetă de peste treizeci de ori. Cu toate acestea, ea nu-şi pierde niciodată încărcătura spirituală, reflexivă, atît de necesară, nu numai pentru repausul descriptiv al aedului, ci și pentru capacitatea receptorilor de a suporta fluxul de detalii crude ale încleștărilor armate corp la corp. Modul în care traducătorii redau aceste construcții, situate între automatismele verbale și ieșirea din ritmul descripțiilor naturaliste, reflectă încă o dată evoluția limbii române, pe de o parte, și calitățile individuale ale traducătorului, pe de altă parte:
a) Căzu, și mîinile’ ambe léntinse la prieteni
b) Iși da și suflarea
c) ...s'a dus, peri Dior.
(CA-I, IV, 523-524, 526)
a) Cade Diores și brațele-ntinde spre bunii tovarăşsi
b) Dîndu-și suflarea din urmă
c) ...pe ochi i se lasă-ntuneric.

(GM-I, IV, 513-514, 516)
a) Diòres cade pe spate și, sleit de puteri, îşi întinde brațele
b) spre tovarășii săi
c) ...Iară beznele morții îi învăluie ochii
(HD-I, IV, 517-526)
a) Se prăbuşi, intinzînd către soții săi dragi stinse brațe
b) Cum sta și sufletu-și da.
c) Peiroos... pe ochi de-i lăsă bezna morții
(DS-I, IV, 523-524, 526).

În textul homeric formula din urmă este relativ fixă, cum spuneam, și impersonală:

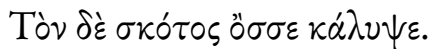

„Intunericul îi acoperă ochii”.

Costache Aristia traduce ideea, nu metafora homerică, el fiind cel care folosește, de data aceasta, expresii din arsenalul metaforic popular românesc: $s$-a dus, pieri. Ceilalți redau enunțul destul de fidel, fiecare în funcție de necesitățile construcțiilor gramaticale, stilistice și prozodice create în românește. Dan Slușanschi personalizează expresia, acțiunea fiindu-i atribuită lui Peiroos. Pare ciudat că Radu Hâncu sare peste expresia b), dintre cele trei discutate aici. Scoase din context, ele apar redundante, este adevărat. De fapt, cele două sintagme care fixează sfîrșitul lui Diores corespund celor două lovituri primite de la Peiroos-prima cu pietroiul cel colțuros, cealaltă, decisivă, cu lancea. Expresia ignorată aici este folosită, 
totuși, cîteva versuri mai jos, căci din tabloul imediat următor aflăm că Peiroos însuși este lovit mortal (de etolul Taos), exact în momentul cînd se concentra să-l răpună definitiv pe Diores. Abia acum se utilizează formula „și viața-i curmă pe vecie”, evitîndu-se, într-adevăr, o reluare la distanță prea mică.

Așadar, scurtele scene de încleștare și moarte se succed rapid, întrerupte doar de perifrazele care îi identifică pe protagoniști și de foarte concentratele notații cu privire la sfirșitul hotărît de destin. Totul este bine integrat în tablouri ample, dominate de dinamism și de un realism atroce. În mod normal, în conformitate cu structura simetric repetitivă a eposului homeric, ar fi trebuit să urmeze un discurs-al învingătorului, care justifică ${ }^{14}$ într-un fel oarecare finalul respectivei înfruntări. Dar, de data aceasta, în colb căzuseră ambii mari conducători-al tracilor și al epeilor, și „alături, mai fură uciși o mulțime” (GM-I, IV, 528). Ideea măcelului general este reluată, de altfel, cîteva versuri mai jos, prin generalizare:

\section{„Droaie de-ahei și troieni căzuseră-n ziua aceea”. \\ (GM-I, IV, 523)}

Așa încît, spune aedul, nici una dintre părți nu ar fi putut să defaime prestația celorlalți (Il., IV, 539). Vorbește din nou, însă, o zeitate, astfel încît simetria compozițională se respectă de două ori: o dată, prin faptul că pasajele discursive de deschidere nu lipsesc, nici chiar din acest fragment puternic marcat de acțiune concretă, și încă o dată, pentru că vorbitorii fac parte din aceeași lume-a ființelor divine, în acest caz.

În afară de cele trei sintagme cu conținut reflexiv-liric strecurate în expunerea obiectivă a faptelor de arme, există însă și una încă mai sintetic formulată, aproape invizibilă, dacă exprimarea ei nu ar fi constat într-un epitet personificator și dacă traducerea românească nu ar fi iscat disimetrii în cazul versiunilor realizate.

Este vorba despre prima dintre „armele” folosite de Peiroos în răpunerea lui Diòres: pietroiul cel colţu-

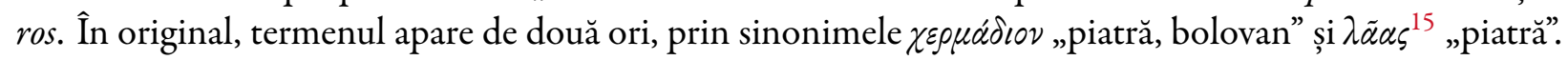

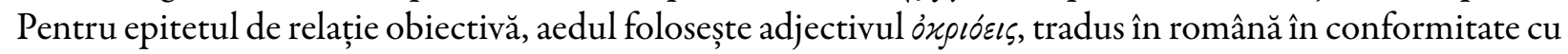
evoluția limbii: sgrebulos, la 1837 (CA-I), ascuțit, la 1928 și 2002 (GM-I și DS-I), colțuros, la 1980 (HD-I). Celălalt epitet reprezintă una dintre acele sintetice interludii lirice care apar frecvent în țesătura epică a episodelor epice din Iliada. Reluînd determinantul inițial (piatră/pietroi), acolo unde aedul grec evitase

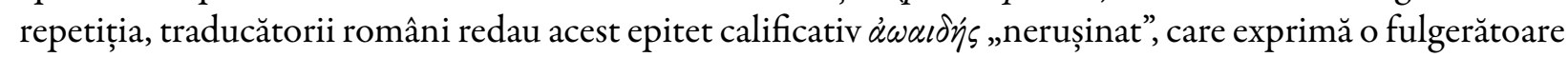
apreciere subiectivă a situației dominate de dinamism, prin „nemilostiv” (GM-I și DS-I) sau „fără de milă” (HD-I). Lui CA-I pare a nu-i fi venit să creadă că epitetul personificator a putut fi folosit în acel loc, așa încît îl ignoră, ca o lecțiune inacceptabilă, preferînd să repete primul adjectiv „sgrebulos”. Or, derivatul prefixat grecesc avea tocmai acest rol, de a sugera, prin personificare oximoronică, acțiunea nemiloasă a Destinului, concretizată într-o piatră. Cînd a apărut prima traducere a lui G. Murnu, unul dintre capetele de acuzare pe care le-a formulat Victor Eftimiu, în celebra critică a versiunii din 1928, a fost tocmai această sintagmă. El, poetul, prozatorul, dramaturgul și gazetarul de mare rafinament, cunoscător al tainelor folosirii conotative, metaforice a ambelor limbi pe care le valorificase și G. Murnu, nu voia să accepte o asemenea asociere, care nu reprezenta altceva decît o banală personificare, la urma-urmelor: „pietroi nemilostiv"? Cum, adică ${ }^{16}$.

Așadar, de-a lungul celor aproape două secole de evoluţie a încercărilor de traducere în română, textele de acest tip din Iliada - caracterizate prin epic condensat, dinamic, naturalist, măiestrit impregnat cu elemente dialogate, descriptive și de discret comentariu liric, toate puse în slujba unui dramatism dus pînă la marginea tragicului (dacă nu s-ar vedea că mentalitatea personajelor le ajută să perceapă faptele după

\footnotetext{
${ }^{14}$ De obicei, discursul învingătorului vizează fapte nedrepte și orgolii ale învinsului, pe care el a reușit, iată, să le pedepsească, cu ajutorul zeilor. Scurta cuvîntare este ea însăşi, însă, un strigăt orgolios de bucurie, o răbufnire verbală după o stare extremă de tensiune trăită în proximitatea morții.

${ }^{15}$ Primul termen este, de fapt, un diminutiv de la $\chi \varepsilon \rho \mu a ́ s$, desemnînd „piatra de aruncat”, folosită ca armă în vremurile homerice, pe cînd al doilea desemnează conceptul de „piatră”, în general.

${ }^{16}$ Cf. Victor Eftimiu, Traducerea „Iliadei”, în: „Opere”, vol. 18, p. 249-288.
} 
codul lor-al onoarei, al eroismului și al încrederii în destin), cu rigorile lor, au putut fi redate în limba naţională a traducătorilor prin căutări succesive, care au condus spre fidelitate față de idee și față de armonia aspră a originalului. Lexic amestecat, ca arii semantice şi ca registre stilistice, gramatică bogată, profund îndatorată exprimării poetice, echilibru între amplitudinea desfăşurării epice și parcinomia comentariului lirico-filosofic, între zăngănitul armelor și măiestria rostirii vorbelor—se regăsesc toate în asemenea pasaje. Termenul vechi, popular și construcția gramaticală pe potrivă au fost folosite la început pentru că altceva nu se afla la îndemîna tălmăcitorului. Apoi, același tezaur de cuvinte și construcții arhaice începe să fie căutat pentru a reda prin el o lume demult apusă, chiar dacă din alte orizonturi geografice și spirituale. Termenul nou, împreună cu creațiile îndrăznețe redau nuanțele, sugestiile implicite descoperite mereu de exegeți în textul original.

\section{Bibliografie}

\section{A. Surse}

\section{A.1. Editiii de text}

Il-A-H-C = Homers, Ilias, K.F. Ameis-C. Hentze-P. Camer, 2 vol. (x 4 facs), ed. 4-8, Leipzig: Teubner, 1905-1932. Reimpr.: Hidesheim, 1970.

Il-M-A = Homer, Iliad, by Monro, D. B. \& Alen, Th. W., Vol. I-II, Clarendon Press, Oxford, $1966^{3}$.

Il-PM = Homère, Iliade, Tomes I-IV. Ed. Paul Mazon et al., Paris: Les Belles Lettres, 1974.

Od-Murray $=$ Homer, The Odyssey with an English Translation by A. T. Murray, Ph.D. in two volumes, Harvard University Press, Cambridge, MA; William Heinemann, Ltd., London, 1919.

PP-I = Iliad online version from the Perseus Project (PP) translation and hyperlinks. (Homeri Opera in five volumes. Ed. D. B. Monro/Th. W. Allen, Oxford: University Press, 1920.)

$\mathrm{PP}-\mathrm{O}=$ Odyssey online version from the Perseus Project (PP) translation and hyperlinks (Homer. The Odyssey with an English Translation by A.T. Murray, PhD in two volumes. Cambridge, MA.: Harvard University Press; London: William Heinemann, Ltd. 1919.).

\section{A.2. Traduceri în română}

\section{A.2.1. Iliada}

CA-I = Omer, Iliada, Tom I. Rapsodiile I-VI. Traducere de D. C. Aristia, Tipografia lui Eliad, Bucureşti, 1837. (versuri albe) DS-I = Homer, Iliada. Tradusă în hexametri, cu o postfaţă, bibliografie şi indici de Dan Sluşanschi şi ilustrată de Mihai Coşulețu, Editura Humanitas, Bucureşti, 2012.

GM-I = Homer, Iiada. În româneşte de George Murnu. Premiul cel Mare al Academiei Române [Bucureşti]: Cultura Națională, [1920].

GMD-I = Homer, Iliada . Traducere în metru original de George Murnu. Studiu introductiv şi note de D. M. Pippidi. Ediţie definitivă. Editura pentru Literatură Universală, Bucureşti, 1967.

$\mathrm{GMF}_{1}-\mathrm{I}=$ Homer, Iliada. Traducere în metru original de George Murnu. Îngrijirea ediţiei, studiu introductiv, note şi glosar de Liviu Franga, Editura Univers, Bucureşti, 1985.

$\mathrm{GMF}_{2}-\mathrm{I}=$ Homer, Iliada. Traducere în metru original de George Murnu. Ediția a II-a, revizuită şi adăugită, cu un studiu introductiv nou, note, notă asupra ediției şi glosar de Liviu Franga, Editura Fundației Culturale, Bucureşti, 1995.

HD-I = Homer, Iliada. Traducere [în proză] de Radu Hâncu, Sanda Diamantescu. Vol. I-II, Editura Minerva, Bucureşti, 1981. RH-I = Homer, Iliada. Traducere de Radu Hâncu. Cuvînt înainte de Gabriela Hâncu, Editura Mondoro - Editura Gramar, Bucureşti, 2011.

\section{A.2.2. Odiseea}

CP-O = Homer, Odysseia, I-XII. Traducere de Cezar Papacostea, 1929. Introducere, notă asupra ediției, note şi indice de Ioana Costa, Bucureşti: Editura Muzeului Literaturii Române, 2013.

Ds-O = Homer, Odysseia . Traducere în hexametri de Dan Sluşanschi. Bucureşti: Editura Paideia, 2009.

Ds-Or = Homer, Odysseia. Traducere în hexametri, cu postfaţă, bibliografie şi indici de Dan Sluşanschi şi ilustrată de Dan Rădvan. Revizuiri şi completări de Octavian Gordon şi Francisca Băltăceanu. Bucureşti: Editura Humanitas, 2012.

EL-O = Homer, Odiseea. Traducere în proză de E. Lovinescu. Cuvînt înainte şi note de Elena Mazilu-Lovinescu, Bucureşti: Editura MondoRo, 1995. 
EL-Or1 = Homer, Odiseea. [Traducere de Eugen Lovinescu. Text revizuit şi note de Traian Costa. Studiu introductiv şi indice de Mihai Nasta], Bucureşti: Editura pentru Literatură, 1963. (Ed. I: 1935)

EL-Or2 = Homer, Odiseea, Vol. I-II. Traducere de Eugen Lovinescu. Text revizuit şi note de Traian Costa. Prefață de Venera Antonescu, Bucureşti: Editura Tineretului, [1966].

EL-Or3 = Homer, Odiseea. Traducere de E. Lovinescu. Ediție revizuită şi postfaţă de Traian Diaconescu. Bucureşti: Saeculum I. O., 1996.

GC-O = Homer, Odiseea, vol. I-II. Traducere de George Coşbuc. Ediţie îngrijită de I. Sfetea şi Şt. Cazimir. Prefaţă de Şt. Cazimir. Bucureşti: Editura pentru Literatură, 1966. (Mss. 1916).

GM-O = Homer, Odissea. Traducere de George Murnu. Studiu introductiv şi note de Adrian Pârvulescu. Bucureşti: Editura Univers, 1979.

GM-Od = Homer, Odiseea. Traducere de George Murnu. Studiu introductiv şi note de D. M. Pippidi. Ediţie definitivă, Bucureşti: Editura Univers, 1971. (Ed. I: 1928)

IC-O = Odiseea. Batrachomyomachia - Războiulşoarecilor cu broaştele. Traducere în proză, note şi prezentări de Ioan Caragiani. Argument. Note asupra ediției de Ion Acsan, Bucureşti: Editura MondoRo, 2011. (Ed. I - Iași: H. Goldner, 1876)

\section{B. Referințe}

Acsan, I. (1984). Constelația corifeilor..., Editura Cartea Românească, Bucureşti.

Ameis, K. F. \& Hentze, C. (1965a). Anhang zu Homers Ilias, ediția a IV-a, vol. I-II, De Gruyter, Amsterdam.

Ameis, K. F. \& Hentze, C. (1965b). Anhang zu Homers Odysee, ediția a IV-a, vol. I-II, De Gruyter, Amsterdam.

Aristotel (1965). Poetica, traducere de D. M. Pippidi, Editura Academiei, Bucureşti.

Bailly, C.A. (1950). Dictionnaire grec-français, Hachette, Paris.

Barbu, N. I.; \& Piatkowski, A. (1978). Scriitori greci şi latini, Editura Ştiinţifică şi Enciclopedică, Bucureşti.

Bârlea, P.Gh. (2008). Limba poveştilor populare româneşti, Editura Academiei Române, Bucureşti.

Bârlea, P. Gh. (2014). Româna literară în fạta poemelor homerice, în: Bârlea, P. Gh. \& Toma, F. R. (coord.), Culturăşsi comunicare, Editura Muzeul Literaturii Române, Bucureşti, p. 27-31.

Bârlea, P.Gh. (2015a). Autohtonizarea textelor homerice în versiunile sud-est europene, în: Spăriosu, L. \& Popovici, V. (coord.), Communication, Culture, Creation: New Scientific Paradigms, Europa Press, Novi Sad - Arad, p. 23-37.

Bârlea, P. Gh. (2015b). Ipostaze ale homerismului în literatura universală, în „Litere”, XVI, 3, (180), p. 67-69.

Camps, W.A. (1980). An Introduction to Homer, Oxford University Press, Oxford.

Chantraine, P. (2009). Dictionnaire étymologique de la langue grecque. Histoire des mots, vol. I-II, Klincksieck, Paris.

Foucault, M. (1998). Ordinea discursului. Un discurs despre discurs, traducere de Ciprian Tudor, Eurosong \& Book, București.

Georgescu, N. (2005). Homer - contemporanul nostru, în: Recife. Eseuri de oceanografie, Editura „Floare Albastră”, Bucureşti, p. $11-51$.

Herescu, N.I. (2011). Destin fără moarte (Pentru clasicism), ediție îngrijită, notă asupra colecției, notă asupra ediției, studiu introductiv de Liviu Franga, Editura Muzeul Literaturii Române, Bucureşti.

Kirk, G. (coord.) (1985-1993). The Iliad: A Commentary, vol. I-VI, Cambridge University Press, Cambridge, CrossRef.

Lascu, N. (1974). Clasicii anticii în România, Editura Dacia, Cluj-Napoca.

Lord, A. (1960). The Singer of Tales, Harvard University Press, Cambridge, MA.

Lovinescu, E. (2012). O privire asupra clasicismului, ediție îngrijită, studiu introductiv, notă asupra ediţiei, note şi comentarii de P. Gh. Bârlea, Editura Muzeul Literaturii Române, Bucureşti.

Marinescu-Himu, M. \& Piatkowski, A. (1972). Istoria literaturii eline, Editura Ştiințifică, Bucureşti.

Meister, K. (1966). Die homerische Kunstsprache, ediția a II-a, Teubner Verlag, Darmstadt - Leipzig, CrossRef.

Parry, M. (1971). The Making of Homeric Verse, în: The Collected Papers of Milman Parry by Adam M. Parry, Oxford University Press, Oxford.

Platon (1983). Opere, vol. IV, ediție îngrijită de Petru Creția, Editura Științifică și Enciclopedică, București.

Risch, E. (1973), Wortbildung der homerischen Sprache, ediția a II-a, De Gruyter \& Co., Berlin - New York, Tome II: Syntaxe (1997), CrossRef.

Wace, A.J.B. \& Stubbings, F. H. (1963). A Companion to Homer, Macmillan \& Co., London - Toronto.

Whitman, C.H. (1958). Homer and the Homeric Tradition, Harvard University Press, Cambridge, MA. 